\title{
Toward artificial developmental regulators
}

\author{
- Supporting Information - \\ Hans-Dieter Arndt, ${ }^{\dagger}$ Karl E. Hauschild, ${ }^{\star}$ David P. Sullivan, ${ }^{\ddagger}$ Kara Lake, ${ }^{\star}$ Peter B. Dervan, ${ }^{\dagger}, *$ and \\ Aseem Z. Ansari,** \\ ${ }^{\dagger}$ California Institute of Technology, Department of Chemistry and Chemical Engineering, \\ Pasadena, CA 91125 \\ ${ }^{\ddagger}$ University of Wisconsin-Madison, Department of Biochemistry and the Genome Center, \\ Madison, WI 53706 \\ *Email: ansari@,biochem.wisc.edu or dervan@caltech.edu
}

\begin{abstract}
Abbreviations. Acetylated bovine serum albumin (BSA), N,N-Dimethylformamide (DMF), Dimethylsulfoxide (DMSO), N,N-Diisopropylethylamine (DIEA), rac-Dithioerythrol (DTT), 4Hydroxy- $\beta$-cyano-cinnamic acid (4-HCCA), ( $N$-[2-Hydroxyethyl]piperazine- $N$ '-[2-ethanesulfonic acid] (HEPES), 1-Hydroxybenzotriazole (HOBt), 1-Hydroxybenzotriazolyl-tetramethyluronium hexafluorophosphate (HBTU), Trifluoroacetic acid (TFA), Trishydroxymethylaminomethane (TRIS).
\end{abstract}

Materials. Boc- $\beta$-Ala-PAM resin $(0.59 \mathrm{mmol} / \mathrm{g})$, anhydrous HOBt and HBTU were purchased from Peptides International. SASRIN ${ }^{\mathrm{TM}}$ resin and all $\mathrm{Fmoc} / \mathrm{tBu}$ protected $\alpha$-amino acids were from Bachem, TFA was from Halocarbon, and DMSO was from Fisher scientific. All other solvents and reagents were anhydrous and/or ACS grade purchased from VWR or Aldrich and used as received. Water was purified using a Millipore MilliQ water purification system (18 M 2 ). Biochemical experiments were performed using RNase free water (Invitrogen). DNase I and calf thymus DNA were purchased from Amersham, all other enzymes and materials for molecular biology was from Roche. All buffers were $0.2 \mu \mathrm{m}$ filtered before storage. Oligonucleotide oligomers were from Integrated DNA Technologies Inc.

Methods. UV spectra were recorded on a HP8452A diode array spectrophotometer. All polyamide compound concentrations were determined by UV spectroscopy $\left(\mathrm{H}_{2} \mathrm{O}\right)$ employing $\varepsilon=69500 \mathrm{Lmol}^{-1} \mathrm{~cm}^{-1}$ at $\lambda_{\max }$ near $312 \mathrm{~nm}$. ESI and MALDI-TOF mass spectra were recorded at the CalTech mass spectrometry service facility on a Finnigan LC-Q ( $2 \mu \mathrm{M}$ in $50 \%$ acetonitrile, $5 \mu \mathrm{L} / \mathrm{min}$ ) or a Perseptive Biosystems Voyager instrument (5 pmol samples in 4-HCCA matrix). 
Analytical HPLC was performed on a Beckman Gold HPLC System fitted with a diode array detector and a Varian-RP18 microsorb column $(250 \times 4.6 \mathrm{~mm})$ at $1 \mathrm{~mL} / \mathrm{min}, 0-100 \% \mathrm{CH}_{3} \mathrm{CN}$ in $0.1 \%$ TFA (v/v) in 30 min. Preparative HPLC was performed on a Beckman Gold HPLC System fitted with a diode array detector and a Waters DeltaPak-RP18 column $(25 \times 100 \mathrm{~mm})$ equipped with a guard, at $8 \mathrm{~mL} / \mathrm{min}\left(0-50 \% \mathrm{CH}_{3} \mathrm{CN}\right.$ in $0.1 \%$ TFA in $50 \mathrm{~min}$, Method $\left.\# 1\right)$, or a DeltaPakRP18 column $(25 \times 100 \mathrm{~mm})$ equipped with a guard attached to a Varian Dynamax-RP18 column $(21.4 \times 250 \mathrm{~mm})$, at $16 \mathrm{~mL} / \mathrm{min}\left(0-40 \% \mathrm{CH}_{3} \mathrm{CN}\right.$ in $0.1 \%$ TFA in $70 \mathrm{~min}$, Method \#2).

Polyamide. Polyamide 1 was synthesized by manual solid phase synthesis following established procedures. ${ }^{[1]}$ Cleavage from PAM resin was accomplished by aminolysis with neat Dimethylaminopropylamine $\left(37^{\circ} \mathrm{C}, 12 \mathrm{~h}\right)$. The volatiles were removed in vacuo, the residue taken up in $10 \% \mathrm{AcOH}$ and purified by prep. HPLC (Method \#2). HPLC $14.6 \mathrm{~min}$. MS (ESI) $[\mathrm{M}+\mathrm{H}]^{+}$calcd for $\mathrm{C}_{59} \mathrm{H}_{76} \mathrm{H}_{23} \mathrm{O}_{10}$ 1266.6, found 1266.4.

Protected peptide acid synthesis. $t$ Bu-protected peptide acids were synthesized by manual solid phase synthesis on SASRIN $^{\mathrm{TM}}$ resin. $^{[2]}$ In brief, $125 \mathrm{mg}$ of SASRIN ${ }^{\mathrm{TM}}$ resin $(1.08 \mathrm{mmol} \mathrm{eq} / \mathrm{g})$ were placed in a presiliconized peptide synthesis vessel, preswollen in $\mathrm{CH}_{2} \mathrm{Cl}_{2}$ (10 min), and combined with a premixed (30 min) and filtered solution of Fmoc-Gly-OH (150 mg, $0.5 \mathrm{mmol}$, 4 eq) in DMF $(125 \mu \mathrm{L})$ and DCC (500 $\mu \mathrm{L}, 1.0 \mathrm{M}$ in $\left.\mathrm{CH}_{2} \mathrm{Cl}_{2}, 0.5 \mathrm{mmol}, 4 \mathrm{eq}\right)$. DMAP (6 mg, $0.05 \mathrm{mmol}, 0.1 \mathrm{eq}$ ) was added, and the mixture was shaken for $12 \mathrm{~h}$. After draining and washing $\left(\mathrm{CH}_{2} \mathrm{Cl}_{2}\right.$, DMF, $\left.\mathrm{CH}_{2} \mathrm{Cl}_{2}\right)$, the loaded resin was capped by treatment with benzoyl chloride/pyridine/ $\mathrm{CH}_{2} \mathrm{Cl}_{2}$ 1:1:3 (1.25 mL) for $30 \mathrm{~min}$. Fmoc deprotection was in general achieved by treatment with $25 \%$ piperidine in DMF ( $3 \times ; 2 \mathrm{sec}, 30 \mathrm{sec}, 15 \mathrm{~min})$, but the second residue was deprotected with $50 \%$ piperidine in DMF $(3 \times ; 2 \mathrm{sec}, 30 \mathrm{sec}, 5 \mathrm{~min})$. Amino acid coupling was performed for $1.5 \mathrm{~h}$ at r.t. using a solution of $0.3 \mathrm{mmol} \mathrm{Fmoc} / \mathrm{Bu}$ protected amino acid in DMF $(0.7 \mathrm{~mL})$ preactivated with $0.3 \mathrm{mmol} \mathrm{HOBt}, 0.27 \mathrm{mmol} \mathrm{HBTU}$ and $50 \mu \mathrm{L}$ of DIEA for $5 \mathrm{~min}$. After $15 \mathrm{~min}$ of coupling time, more DIEA $(20 \mu \mathrm{L})$ was added to the mixture. After successive build-up of the peptide chain, the terminal Fmoc group was removed and the resin bound peptide treated with a mixture of $\mathrm{Ac}_{2} \mathrm{O} /$ pyridine/DMF 2:3:10 (1 mL) for $30 \mathrm{~min}$ followed by thorough washing (DMF, $i \mathrm{PrOH}, \mathrm{DMF}, \mathrm{CH}_{2} \mathrm{Cl}_{2}$ ). The peptide was cleaved from the resin in four cycles, where the resin was treated with TFA/Ethanedithiol/ $\mathrm{Et}_{3} \mathrm{SiH} / \mathrm{CH}_{2} \mathrm{Cl}_{2}$ 1:5:5:89 $(1.5 \mathrm{~mL})$ for $15 \mathrm{~min}$. After each cycle, the resin was drained, and the obtained solution was 
immediately cooled to $0^{\circ} \mathrm{C}$ and neutralized with pyridine $(20 \mu \mathrm{L})$. All cleavage solutions were combined and partitioned between EtOAc $(70 \mathrm{~mL})$ and $0.1 \mathrm{M} \mathrm{KHSO}_{4}(30 \mathrm{~mL})$. The organic layer was washed with brine $(2 \times 20 \mathrm{~mL})$, dried with $\mathrm{Na}_{2} \mathrm{SO}_{4}$, and the volatiles were evaporated. Purification of the residue by flash column chromatography ( $20 \mathrm{~g}$ of silica) yielded the pure peptide acids. Peptide 4: Yield $148.5 \mathrm{mg}$ (121 $\mu \mathrm{mol}, 88 \%)$; TLC $\left(\mathrm{CH}_{2} \mathrm{Cl}_{2} / \mathrm{MeOH} / \mathrm{HCOOH} 100: 5: 1\right)$ $R_{f}=0.16$; HPLC 23.4 min; MS (ESI, neg.) [M-H] ${ }^{-}$calcd for $\mathrm{C}_{63} \mathrm{H}_{86} \mathrm{~N}_{9} \mathrm{O}_{14} \mathrm{~S}$ 1224.6, found 1224.5. Peptide 5: Yield $54.2 \mathrm{mg}$ (57 $\mu \mathrm{mol}, 42 \%)$; TLC $\left(\mathrm{CH}_{2} \mathrm{Cl}_{2} / \mathrm{MeOH} / \mathrm{HCOOH} 100: 10: 1\right) R_{f}=0.19$; HPLC 18.0 min; MS (ESI, neg.) [M-H] $]^{-}$calcd for $\mathrm{C}_{48} \mathrm{H}_{69} \mathrm{~N}_{8} \mathrm{O}_{12}$ 949.5, found 949.5.
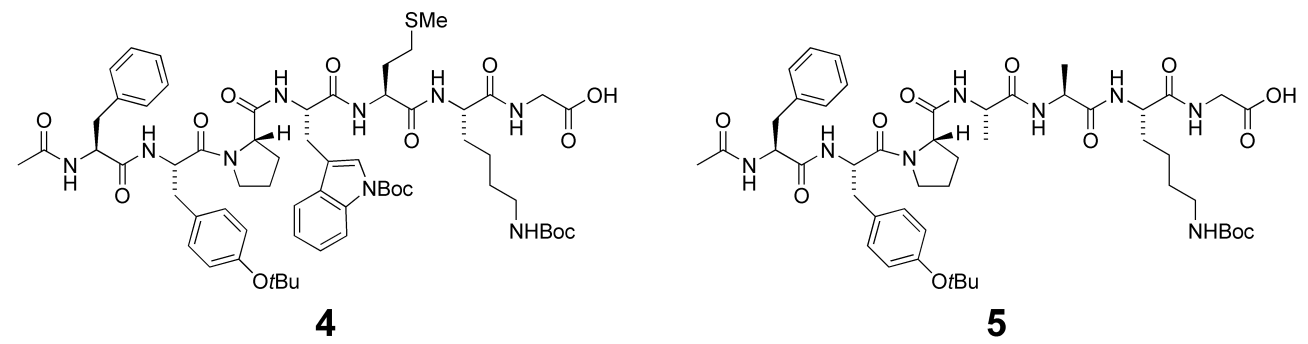

Synthesis of the polyamide-peptide conjugates. A solution of $10 \mu \mathrm{mol}$ (4 eq.) of the respective peptide acid in $\mathrm{CH}_{2} \mathrm{Cl}_{2} / \mathrm{DMF}$ 10:1 $(2.5 \mathrm{~mL})$ was treated at r.t. with $0.1 \mathrm{M} \mathrm{HBTU}$ in DMF $(110 \mu \mathrm{L}, 11 \mu \mathrm{mol})$ and $1.0 \mathrm{M}$ DIEA in DMF $(12 \mu \mathrm{L}, 12 \mu \mathrm{mol})$ for $5 \mathrm{~min}$, before approx. $2.5 \mu \mathrm{mol}$ of polyamide $1 \mathrm{TFA}$ salt in DMF $(2.5 \mathrm{~mL})$ were added, followed by $12 \mu \mathrm{L}$ of $1.0 \mathrm{M}$ DIEA in DMF. After the conversion was complete ( $\mathrm{h}$, HPLC control), the volatiles were removed in vacuo, and the residue was dissolved in TFA/ $\mathrm{CH}_{2} \mathrm{Cl}_{2} /$ Ethanedithiol/ $/ \mathrm{Et}_{3} \mathrm{SiH}$ 80:10:5:5 $(1 \mathrm{~mL})$. After $20 \mathrm{~min}$, the crude peptides were precipitated with cold $\mathrm{Et}_{2} \mathrm{O}\left(10 \mathrm{~mL}, 0^{\circ} \mathrm{C}\right)$ and isolated by centrifugation and discarding of the supernatant. The colorless powder was resuspended twice in $\mathrm{Et}_{2} \mathrm{O}\left(5 \mathrm{~mL}, 0^{\circ} \mathrm{C}\right)$, reisolated by centrifugation, and then taken up in $0.2 \mathrm{M} \mathrm{AcOH}$. After standing for $4 \mathrm{~h}$, this solution was purified by prep. HPLC (Method \#l) to yield the conjugates in $>97.5 \%$ HPLC purity $(312 \mathrm{~nm})$. Conjugate 2 : Yield $3.7 \mathrm{mg}(1.66 \mu \mathrm{mol}, 62 \%)$ from 4 and $2.67 \mu \mathrm{mol}$ 1; HPLC $17.0 \mathrm{~min}$; MS (MALDI-TOF) $[\mathrm{M}+\mathrm{H}]^{+}$calcd for $\mathrm{C}_{108} \mathrm{H}_{137} \mathrm{~N}_{32} \mathrm{O}_{19} \mathrm{~S}$ 2218.1, found 2218.0. Conjugate 3: Yield $1.4 \mathrm{mg}(0.72 \mu \mathrm{mol}, 26 \%)$ from 5 and $2.8 \mu \mathrm{mol} \mathbf{1}$; HPLC $15.5 \mathrm{~min}$; MS (MALDI-TOF) [M+H] $]^{+}$calcd for $\mathrm{C}_{98} \mathrm{H}_{128} \mathrm{~N}_{31} \mathrm{O}_{19}$ 2043.0, found 2042.9.

DNase I footprinting. Dissociation constants for the DNA binding of compounds 1, 2 and 3 were obtained following published protocols. ${ }^{[3]}$ All reactions were carried out in $400 \mu \mathrm{L}$ total volume employing $20 \mathrm{kcpm}$ of a 3'-radiolabelled 250-bp restriction fragment from the plasmid 
pDEH9 (Figure S1 a). No carrier DNA was used in the equilibration, and the solutions were allowed to equilibrate for $12 \mathrm{~h}$ at $22^{\circ} \mathrm{C}$ in TKMC buffer $(10 \mathrm{mM}$ TRIS, $10 \mathrm{mM} \mathrm{KCl}, 5 \mathrm{mM}$ $\left.\mathrm{MgCl}_{2}, 5 \mathrm{mM} \mathrm{CaCl} 2 ; \mathrm{pH} 7.0\right)$ prior to the DNase I digestion. Reaction products $(8 \mathrm{kcpm})$ were resolved on denaturing $8 \%$ polyacrylamide sequencing gels run at $55 \mathrm{~W}$.

a)

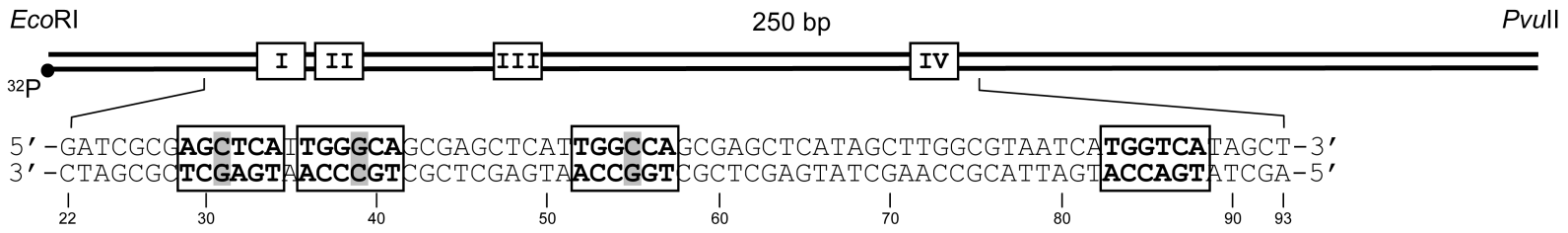

b)

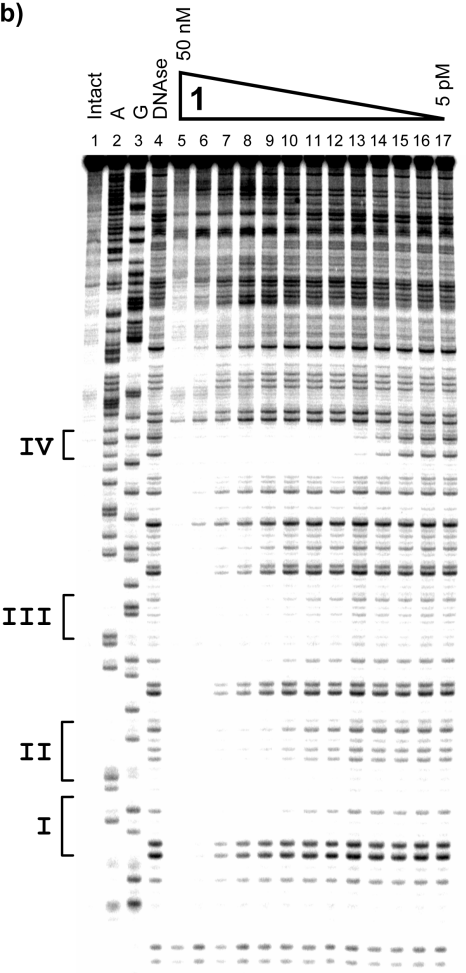

c)

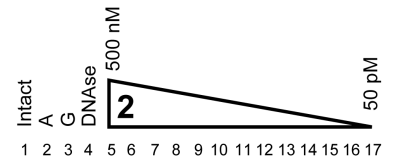

IV [

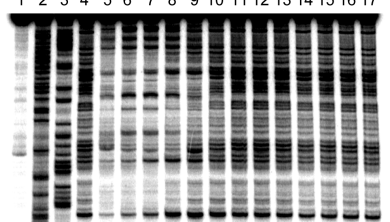

[
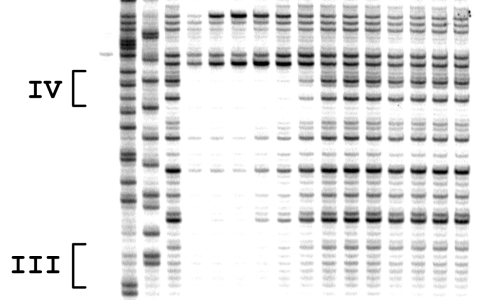

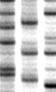

$-$

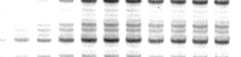

- - 프르프는

-

I $=$ =

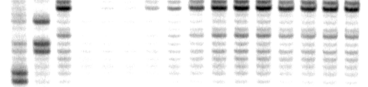

$=$

$\underline{z}=$

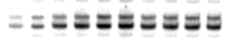

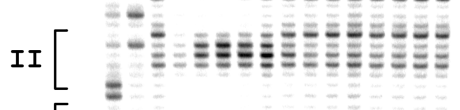

$I[$

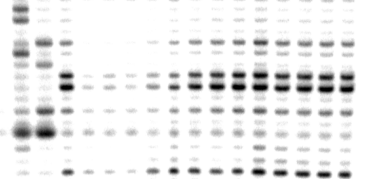

d)

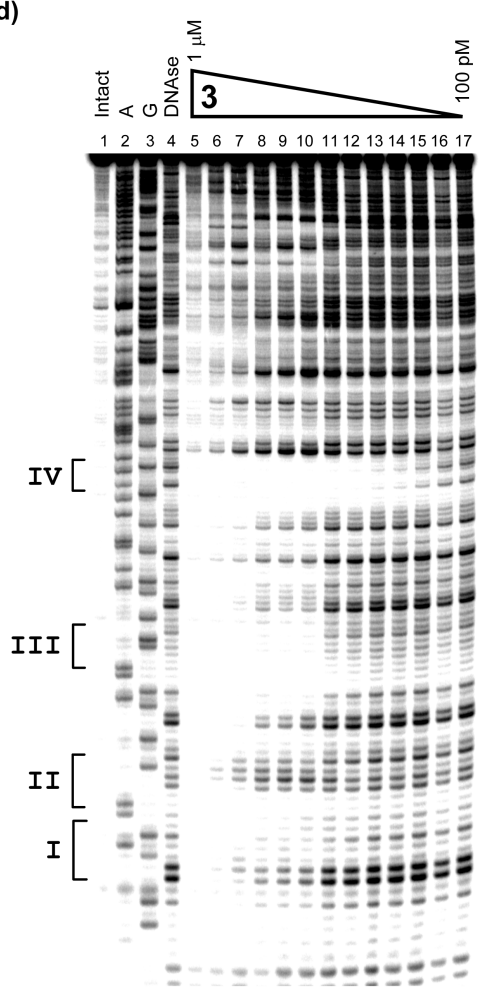

Figure S1. a) Overall composition and insert sequence of the EcoRI/Pvull restriction fragment from the plasmid pDEH9. Polyamide binding sites are highlighted with boxes, mismatched base pairs are shaded in gray. The site of the $3{ }^{\prime}-{ }^{32} \mathrm{P}$-labeling is indicated (lower strand). b)-d) Quantitative DNAse 1 footprint titration experiments for compounds 1, 2 and 3 on the 3 '- ${ }^{32} \mathrm{P}$-labeled 250 -bp EcoRI/Pvull restriction fragment from the plasmid pDEH9. Lane 1: Intact DNA. Lane 2: A-reaction. Lane 3: G-reaction. Lane 4: DNAse 1 standard. b) Compound 1 Lane 5-17: 50 nM, 20 nM, 10 nM, 5 nM, 2 nM, 1 nM, 500 pM, 200 pM, 100 pM, 50 pM, 20 pM, 10 pM, 5 pM; c) Compound 2 Lane 5-17: 500 nM, 200 nM, 100 nM, 50 nM, 20 nM, 10 nM, 5 nM, 2 nM, 1 nM, 500 pM, 200 pM, 100 pM, 50 pM; d) Compound 3 Lane 5-17: $1 \mu \mathrm{M}, 500$ nM, 200 nM, 100 nM, 50 nM, 20 nM, 10 nM, 5 nM, 2 nM, 1 nM, 500 pM, 200 pM, $100 \mathrm{pM}$, respectively. The analyzed binding site locations are indicated with square brackets along the left side of each autoradiogram. 
Protein expression. Drosophila extradenticle (Exd) protein comprising the homeodomain and the extended fourth helix (residues 238-324), ${ }^{4}$ as well as ultrabithorax (Ubx) protein homeodomain (residues 233-313 of the Ubx isoform IVa) was expressed and purified after Passner and Aggarwal. ${ }^{5}$ The purified proteins Exd and Ubx were used for EMSA studies as described below.

\section{EMSA (gel shift) studies.}

For the templates, following DNA oligos were used (see below). The DNA upper strand was annealed with the respective matching lower strand and both strands were 5 '-labeled with $\gamma-{ }^{32} \mathrm{P}-$ ATP and polynucleotide kinase, using standard procedures.

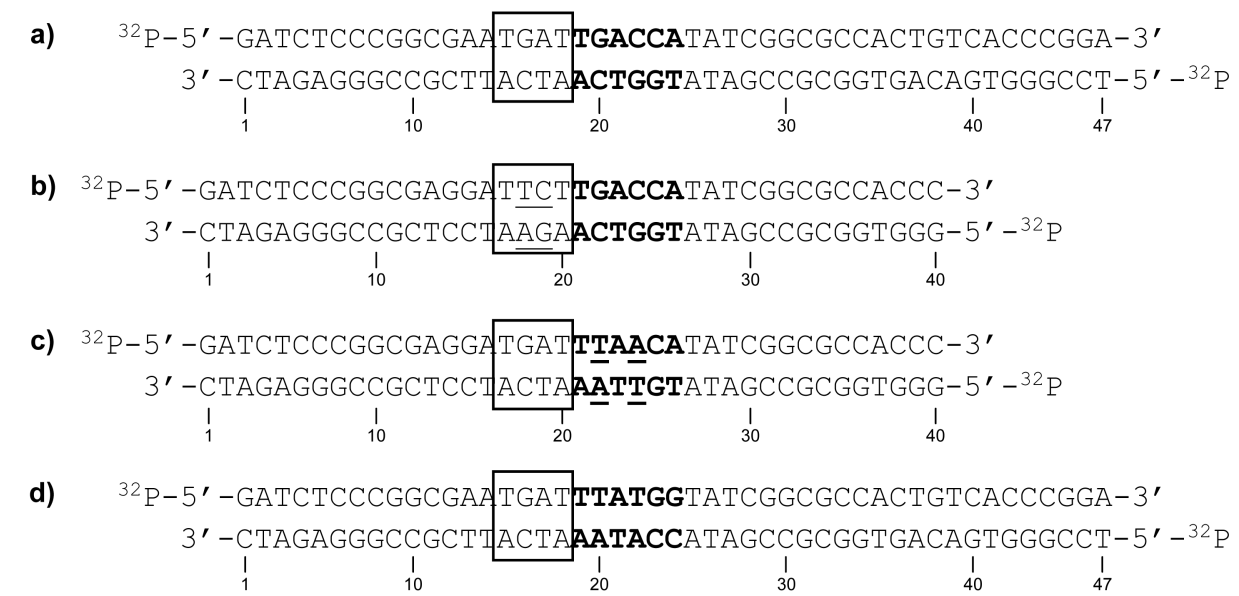

Figure S2. DNA duplexes used for the EMSA studies. The binding site for the Exd protein is marked by a box, the polyamide or Hox protein binding site is shown in boldface. a) Optimal template; b) 2-bp mismatch in the Exd site; c) 2-bp mismatch in the PA binding site; d) composite Ubx-Exd binding site (see ref. 5).

Gel-shift experiments: The master mix contained 50\% BSA/50\% glycerol, reaction buffer (150 mM potassium glutamate, $50 \mathrm{mM}$ HEPES pH 7.0, $1 \mathrm{mM}$ DTT) and 5'-end labeled DNA $\left({ }^{32} \mathrm{P}\right)$. The final concentrations in the samples were $100 \mathrm{ng} / \mu \mathrm{L}$ BSA and $10 \%$ glycerol. Polyamides were kept in subdued lighting whenever possible. Upon addition of the polyamide to 1 pM DNA the samples were incubated at $25^{\circ} \mathrm{C}$ for 30 minutes in a $20 \mu \mathrm{L}$ reaction. Next, Exd was added to the samples and incubated for 1 hour at $4{ }^{\circ} \mathrm{C}$. A $9 \%$ acrylamide/3\% glycerol gel was pre-run for $15 \mathrm{~min}$ prior to loading. In each lane $15 \mu \mathrm{L}$ of a $20 \mu \mathrm{L}$ reaction were loaded while the gel was running, to prevent the samples from being diluted. The gels were run at $4^{\circ} \mathrm{C} / 185 \mathrm{~V}$. Gels were dried, exposed to a phosphorimager screen, and visualized using a Molecular Dynamics phosphorimager. 
a)

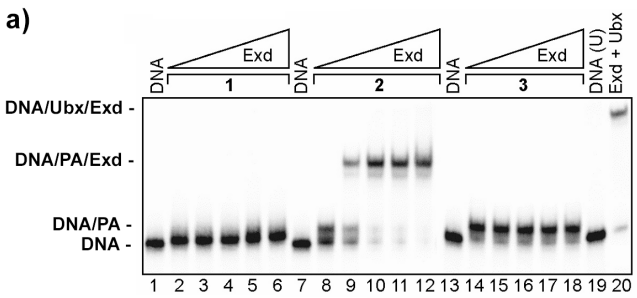

b)

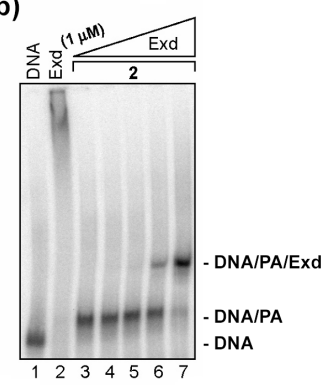

Figure S3. EMSA studies with polyamides 1-3, Exd and Ubx. a) Each polyamide binds and decreases the mobility of free DNA (lanes 2-18). Compound 2 bearing the functional docking peptide is capable of recruiting Exd to DNA (lanes 9-12) whereas 1 \& 3 are not. In lanes 2-6, 8-12, 14-18, Exd was added in following concentrations: 0, 3, 10, 30, 100 nM. Lanes 19 and 20 contained DNA bearing the Exd-Ubx binding site that was used in X-ray crystal structure determination (see methods above for sequence). In the reaction shown in lane 20, $275 \mathrm{nM}$ Ubx and $30 \mathrm{nM}$ Exd were incubated with DNA. b) Multiple Exd molecules bind DNA at $1 \mu \mathrm{M}$ concentration (lane 2), reactions in lanes 3-7 contain 50 nM PA 2 and increasing concentration of Exd (0, 0.3, 1, 3, 10 nM in lanes 37).

Gel-shift studies with the Ubx protein were performed under identical buffer conditions using the duplex oligonucleotide listed in Figure S2 (d). Ubx was added to the reaction mixture containing ${ }^{32} \mathrm{P}$ end-labeled duplex DNA and incubated at $4{ }^{\circ} \mathrm{C}$ for $30 \mathrm{~min}$. Subsequently Exd was added and the reaction was further incubated for $60 \mathrm{~min}$ at $4{ }^{\circ} \mathrm{C}$. The complexes were resolved under similar gel conditions as those described for DNA-polyamide-Exd complexes above. The $K_{\mathrm{d}}$ of Ubx for its cognate DNA was found to be $200 \pm 25 \mathrm{nM}$. Under saturating concentrations of Ubx (325 nM) the affinity of Exd for the binary [Ubx-DNA] complex was 2-3 fold larger than the affinity of Exd for the conjugate $2 \cdot$ DNA binary complex. ${ }^{6}$

\section{References.}

[1] Baird, E. E.; Dervan, P. B. J. Am. Chem. Soc. 1996, 118, 6141-6146.

[2] Mergler, M.; Gosteli, J.; Grogg, P.; Nyfeler, R.; Tanner, R. Chimia 1999, 53, 29-34.

[3] Trauger, J. W.; Dervan, P. B. Methods Enzymol. 2001, 340, 450-466.

[4] Piper, D. E.; Batchelor, A. H.; Chang, C.-P.; Cleary, M. L.; Wolberger, C. Cell 1999, 96, 587-597.

[5] Passner, J. M.; Ryoo, H. D.; Shen, L.; Mann, R. S.; Aggarwal, A. K. Nature 1999, 397, 714719.

[6] Brezinski, M.; Warren, C. L.; Ansari, A. Z.; to be detailed elsewhere. 